\title{
EXPRESSION OF GENES, ENCODING THE ENZYMES OF CYSTEINE METABOLISM IN HUMAN PLACENTA IN THE FIRST AND THIRD TRIMESTERS OF UNCOMPLICATED PREGNANCY
}

\author{
K. L. KORNEEVA', R. R. RODRIGUEZ1, S. V. RALCHENKO², O. V. MARTUNOVSKA ${ }^{2}$, \\ A. O. FROLOVA ${ }^{1}$, O. P. MARTSENYUK ${ }^{1}$, L. V. MANZHULA ${ }^{3}$, V. T. MELNYK ${ }^{4}$, \\ O. Y. SHKOROPAD ${ }^{4}$, M. YU. OBOLENSKA ${ }^{1}$ \\ ${ }^{1}$ Institute of Molecular Biology and Genetics, National Academy \\ of Sciences of Ukraine, Kyiv; \\ ${ }^{2}$ Taras Shevchenko National University of Kyiv, Ukraine; \\ ${ }^{3}$ Maternity Hospital of Kyiv $N$ 3, Ukraine; \\ ${ }^{4}$ Maternity Hospital of Irpin, Ukraine; \\ e-mail:m.obolenska@gmail.com
}

The cellular cysteine is highly regulated in a narrow range of concentrations due to its cyto- and neurtoxicity when it is overwhelmed or its deficiency for protein synthesis and other vital metabolic reactions when its amount is restricted. The regulation of cysteine content and its metabolic products, glutathione, taurine and inorganic sulfur compounds, is scarcely explored in human placenta though cysteine metabolism is closely related to the maintenance of redox status and protection from free radical oxidation, elimination of homocysteine and detoxification. These processes are particularly important for placenta which meets substantial changes of oxygen supply during its development, and is the last metabolically active organ between mother and fetus. The abundance of CDO, CSAD, ADO, SUOX, GCLC and GCLM mRNAs was estimated by RT-qPCR and compared with the computationally analyzed microarray gene expression data from GEO, while the level of individual protein - by western-blot analysis, both in placental samples from first and third trimesters of uncomplicated pregnancies. The abundance of CDO mRNA is significantly up-regulated at term compared to the first trimester, the level of GCLM and GCLC mRNAs remains almost unchanged while the abundance of other mRNAs reduces to varying degrees. Overall, the changes of gene expression in third trimester in comparison to the first one estimated by RT-qPCR and microarray coincide while the former data are more informative for the limited group of genes. The data provide the basis for further research of these genes expression and phenotype of human placenta in health and disease

Ke y word s: human placenta, gene expression, enzymes of cysteine metabolism.

$\mathrm{H}$ uman placenta is involved not only in the transport of substances between mother and her child, but it is a metabolically active organ, which activity depends on the stage of organ development, state of maternal metabolism, her diet and lifestyle. Disorder in placental metabolism adversely affects fetal development and maternal health, and also affects the health of the child and mother later in their life [1-3]. In this paper, the authors have focused on the study of genes expression involved in cysteine metabolism in human placenta. L-cysteine is an essential amino acid. It enters the body with diet and is synthesized in the homocystei- ne transsulfuration pathway $[4,5]$. The latter process is a key to homocysteine utilization and failures in this pathway can lead to accumulation of toxic homocysteine [5].

Cysteine concentration in the cell has to be in the balanced state providing the processes of protein synthesis, production of glutathione, the biosynthesis of coenzyme A and taurine, the elimination of sulfur compounds through the formation of non-hazardous organic and inorganic derivatives [6, 7]; and at the same time it has to be maintained at a level below the threshold of cytotoxicity due to cysteine tendency to autoxidation causing oxidative stress $[8,9]$. Both 
accumulation and shortage of cysteine during pregnancy especially in the placenta lead to pathological consequences.

The formation of non-toxic end products of cysteine catabolism occurs via two main ways, namely direct oxidation (cysteine sulfinatedependent pathway) and 3-mercaptopyruvate pathway, i.e. by transamination. The formation of inorganic sulfate and organic compounds such as hypotaurine/taurine, as well as glutathione synthesis as temporary nontoxic storage for cysteine, enable to keep a balance of cysteine within certain limits to provide the necessary tissue metabolites and maintain the cellular redox potential. Given the natural changes of oxygen supply in the placenta during pregnancy, maintaining the redox potential of tissue is particularly important for the placenta and fetus development [10]. So the transition from the first trimester of pregnancy when the placenta and fetus exist with almost no access to external oxygen, into the second trimester is accompanied by dramatic increase of oxygen access to placenta, when blood exchange with maternal organism is established $[1,11]$.

The general scheme of cysteine transformation is represented in Fig. 1. In the first step of cysteine catabolism via the cysteine sulfinate-dependent pathway the non-heme iron cytosolic enzyme cysteine dioxygenase (CDO, EC 1.13.11.20) catalyzes the incorporation of two atoms from molecular oxygen into the cysteine structure to form cysteine sulfinate. This reaction is irreversible. Next, cysteine sulfinate is decarboxylated by pyridoxal phosphate-dependent enzyme cysteine sulfinate decarboxylase (CSAD, EC 4.1.1.29) to form hypotaurine or converted into pyruvate and sulfite by aspartate aminotransferase (EC 2.6.1.1). It is believed that CSAD is the ratelimiting enzyme in the hypotaurine biosynthesis pathway $[12,13]$. The oxidation of sulfite to sulfate is the final step in the catabolism of many sulfurcontaining compounds. This reaction is catalyzed by the enzyme sulfite oxidase (SUOX; EC 1.8.3.1) located in the mitochondria and uses cytochrome $C$ as a terminal electron acceptor. [14].

There is an alternative pathway of hypotaurine synthesis from cysteine associated with the synthesis and degradation of coenzyme A to cysteamine with its subsequent oxidation by 2-aminoethanethiol dioxygenase (ADO, EC 1.13.11.19). Hypotaurine is further oxidized to taurine $[15,16]$.

Cysteine is required for the glutathione synthesis. Formation of $\gamma$-glutamylcysteine is the first and limiting step in the synthesis of glutathione and catalyzed by glutamate-cysteine ligase (GCL, EC 6.3.2.2), consisting of two subunits - catalytic (GCLc) and modifier (GCLm). Joining modifier subunit to catalytic regulates enzyme activity. Both subunits are encoded by different genes in mammals [17].

Despite a rather thorough study of cysteine metabolism and expression of respective genes in the mammalian liver [5], similar processes in the human placenta are almost unstudied. Human placenta differs significantly from the liver in the pattern of expressed enzymes and the level of their expression [18-20] which are unique at each stage of placental development. Though the cysteine metabolism in the placenta is poorly investigated, there is a relatively large amount of indirect data pointing to its significance, e.g. oxidative stress in the organ plays a significant role in numerous complications of pregnancy, especially in preeclampsia [19-21]; high concentration of total cysteine in plasma of pregnant women is accompanied by an increased risk of preeclampsia, premature birth and low birth weight [9]; the elevated cysteine concentration in placenta at $\mathrm{C} / \mathrm{T}$ genotype of methylentetrahydrofolatereductase reduces the glutathione concentration [19]; transport of taurine through the placenta is important for placental cells differentiation and it is associated with mother obesity [22, 23].

The aim of our study was to assess expression of genes encoding enzymes involved in the cysteine metabolism in human placenta from uncomplicated pregnancy by determining the abundance of respective mRNAs in human placental samples from the first and third trimesters of gestation. This study is a part of folate-dependent and associated processes research in human placenta in uncomplicated and complicated pregnancy which is conducted in the laboratory of systems biology IMBG NAS of Ukraine [19, 20, 24, 25]. The obtained data will form the basis for further research of these enzymes expression and placental phenotype on the whole in health and disease. Our research contemporizes with the launching of "The human placenta project" initiated by the National Institute of Child Health and Human Development, USA (https://www.nichd.nih. gov/research/HPP/Pages/default.aspx) [26].

\section{Materials and Methods}

Samples collection. All studies were performed in accordance with the terms of the Helsinki Decla- 


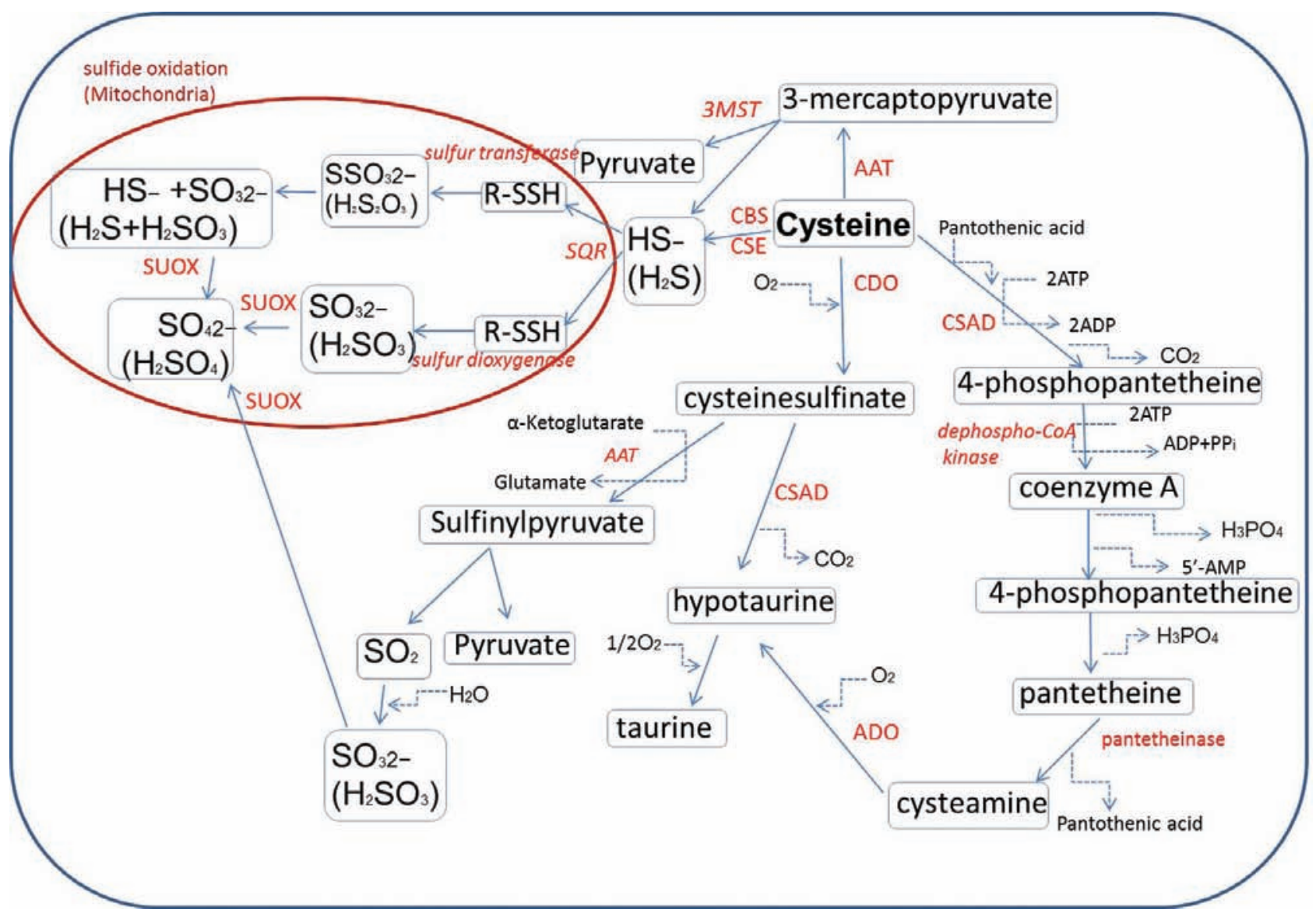

Fig. 1. Metabolic pathways of cysteine desulfuring (Adapted from Feng et al., 2007; Stipanuk and Ueki, 2011). Abbreviations: AAT - aspartate aminotransferase; ADO - 2-aminoethanethiol-dioxygenase; CBS - cystathionine $\beta$-synthase; CDO - cysteine dioxygenase; CSAD - cysteine sulfinic acid decarboxylase; CSE cystathionine- $\gamma$-lyase; MST - 3-mercaptopyruvatesulfurtransferase; SQR - sulfide:quinone oxidoreductase; SUOX - sulfiteoxydase

ration. Ethics Committee of the Institute of Molecular Biology and Genetics of the National Academy of Sciences of Ukraine approved the study protocol and the use of human tissue. All women whose placental samples were used in the experiment had given written consent.

Samples of term placenta (8 samples, $279 \pm 11$ days of pregnancy) were obtained in the maternity hospital No 3 (Kyiv, Ukraine). Samples of the placenta from the middle of the first trimester of pregnancy (9 samples, 6-7 weeks) were obtained after abortion in maternity hospital of Irpin (Irpin, Ukraine). All samples were obtained from women with physiological pregnancy. Clinical data on mother and child were obtained from medical records. Placental samples were taken immediately after abortion or birth, washed in cold sterile physiological solution, frozen in liquid nitrogen and stored at $-70^{\circ} \mathrm{C}$ before the use in research. Samples of term placenta (20 g) were taken from the central part of the organ through all layers.

RNA isolation and detection of gene expression. Total RNA was isolated using Trizol reagent (Neogene, Ukraine) according to manufacturer's recommendations. The quantity and quality of obtained RNA was monitored by absorbance ratio at 260/280 and 260/230 nm (NanoDrop 2000, Thermo Scientific, USA) and the intensity of specific bands of 28S/18S rRNA (agarose gel electrophoresis).

The abundance of individual mRNAs in total RNA was determined by reverse transcription and quantitative polymerase chain reaction (RT-qPCR) in real time with the amplification device Bio-Rad CFX96 Real-Time PCR Detection System (Bio-Rad Laboratories Ltd., USA). Reverse transcription was performed using the First Strand cDNA Synthesis Kit (\# K1612, Thermo Scientific) according to the manufacturer's protocol: $5 \mu \mathrm{g}$ of RNA in $50 \mu \mathrm{l}$ reac- 
tion mixture containing random hexamer primers and revertase were sequentially incubated for $10 \mathrm{~min}$ at $25^{\circ} \mathrm{C}$, for $60 \mathrm{~min}$ at $37^{\circ} \mathrm{C}$ and for $5 \mathrm{~min}$ at $70^{\circ} \mathrm{C}$. After the reaction was completed, mixture was aliquoted and kept at $-20^{\circ} \mathrm{C}$.

The reaction mixture for amplification, $25 \mu 1$, contained $2 \mu 1$ of cDNA, $10 \mu \mathrm{l}$ of $2.5 \mathrm{x}$ SYBR ${ }^{\circledR}$ Green I buffer (Syntol, Russia, \#M-427) and 10 pmol of each primer. Thermal cycling conditions were as follows: initial denaturation for $3 \mathrm{~min}$ at $95{ }^{\circ} \mathrm{C}, 40$ cycles of $10 \mathrm{~s}$ at $95^{\circ} \mathrm{C}, 20 \mathrm{~s}$ at $60^{\circ}$, and $30 \mathrm{~s}$ at $72^{\circ} \mathrm{C}$. The final elongation was for $1.5 \mathrm{~min}$ at $72{ }^{\circ} \mathrm{C}$. The specificity of amplification was controlled using melting curve in the range $55-95{ }^{\circ} \mathrm{C}$ with increment of $0.5^{\circ} \mathrm{C}$ and gel electrophoresis of amplified product.

The data were analyzed using the software Bio-Rad CFX-manager (Bio-Rad, USA) and LibreOfficeCalc (The Document Foundation, Germany). The number of copies of each transcript per $1 \mathrm{ng}$ of total RNA was calculated using standard curves. Standard curves for quantification of each transcript in total RNA were obtained using 10-fold dilutions of corresponding amplicon of cDNA fragments in the range of $1 \mathrm{fmol}$ to $0.001 \mathrm{amol}$ in $25 \mu \mathrm{l}$ of PCR mixture. For the purpose of standardization cDNA amplicons were obtained in $150 \mu \mathrm{l}$ of PCR mixture, purified by a GeneJET PCR purification kit (Thermo Scientific, USA), and quantified with a spectrophotometry. The validity of amplicons was controlled by restriction analysis (Table 1). Amplification efficiency was $\sim 90 \%$ for all pairs of primers.

The primers for each cDNA were designed with online application PrimerQuest (Integrated DNA Technologies, Inc., USA), their specificity was tested by online tool BLAST (NCBI, USA). Primers were synthesized in IMBG NASU (Ukraine) and Syntol (Russia). To avoid amplification of genomic DNA fragment, primers were designed in such way that the forward and/or reverse primer overlapped the junction of two exons. The negative control containing distilled water instead of cDNA was always placed simultaneously with samples in the same plate.

Western blot analysis of cysteine dioxygenase content. Placental samples about $150 \mathrm{mg}$ (3 samples from the first and 3 samples from third trimesters of pregnancy) were homogenized in RIPA lysis buffer (0.05 M Tris, pH 7.4, 1\% NP-40, 0.1\% SDS, $150 \mathrm{mM}$ $\mathrm{NaCl}, 0.5 \%$ sodium deoxycholate, $1 \mathrm{mM}$ EDTA). The homogenate was centrifuged at $15000 \mathrm{~g}$, at $4{ }^{\circ} \mathrm{C}$ for $20 \mathrm{~min}$. The supernatant in an amount corresponding to $50 \mu \mathrm{g}$ of total protein were mixed with 4x Protein loading buffer (Thermo Fisher Scientific, USA), incubated for $10 \mathrm{~min}$ at $95^{\circ} \mathrm{C}$ and subjected to $5-12 \%$ PAGE in denaturing conditions. Semi-dry transfer of proteins to PVDF membrane was performed for $30 \mathrm{~min}$. The quality of the transfer was monitored by staining membranes with Ponceau S.

The membrane was washed with TBS buffer (10 mM Tris, $\mathrm{pH} 7.5,100 \mathrm{mM} \mathrm{NaCl}$ ), blocked for $60 \mathrm{~min}$ in 5\% skim milk and again washed with buffer TBS three times and then incubated with primary antibodies anti-Cysteine Dioxygenase Type 1 (ab150705) (Abcam, UK) overnight at $4{ }^{\circ} \mathrm{C}$. After incubation the membrane was washed in buffer TTBS (10 mM Tris, pH 7.5, $100 \mathrm{mM} \mathrm{NaCl}, 0.1 \%$ Tween 20) and incubated with secondary antibody goat antirabbit IgG-HRP: sc-2030 (Santa Cruz Biotechnology, USA) for $60 \mathrm{~min}$ at room temperature.

Membrane was processed with chemiluminescent reagent Clarity Western System (BIO-RAD Laboratories, USA) according to the manufacturer's instructions. The signals were detected with ChemiDoc (BIO-RAD, Laboratories, Inc., Hercules, California, USA). The total optical density of electrophoretic bands of each track was evaluated by GelPro 3.1 software. To normalize the protein abundance membrane was incubated with primary antibodies anti-GAPDH (FL-33.5) (Santa Cruz Biotechnology, USA) followed by treatment similar to the above.

Data analysis of microarray-experiments. We compared our results for mRNAs abundance with the results of microarray experiments conducted on 12 samples from the first trimester and 9 samples of term placenta. The data is available in the database GEO (Gene Expression Omnibus) by the number GSE9984 [27]. We conducted a re-analysis of Affymetrix CEL files (CEL files containing information about the signal strength of each microarray sample) in order to use the new annotation of genes that appeared since the first data analysis and to check data quality. Analysis was conducted with software R version 3.1.2 using packages "Bioconductor", RMA method to normalize the data and array Quality Metrics package for data quality control. To build a linear model and to find differentially expressed genes we used package "limma". Annotations of genes were carried out using the package "hgu133plus2. $\mathrm{db}$ ”, version 3.0.0.

Statistical analysis. All data on mRNA abundance are represented in copies of mRNA in $1 \mathrm{ng}$ 


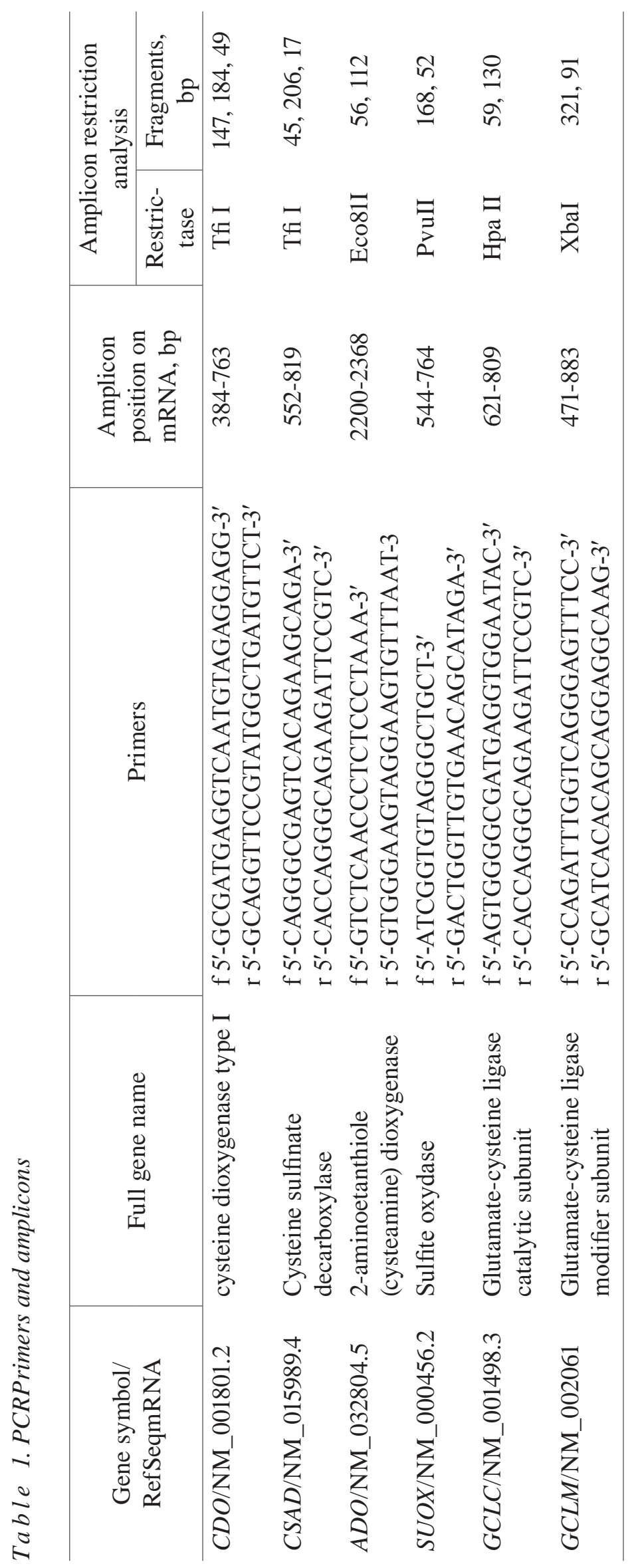


of total RNA. Due to the discrepancy between the data and Gaussian distributions, the data are presented in medians and two quartiles, lower $\left(\mathrm{Q}_{\text {lower }}\right)$ and upper $\left(\mathrm{Q}_{\text {upper }}\right)$ as well as in the ratio of values of gene expression in the first and third trimesters. The significance of the differences between the values of gene expression in the first and third trimesters was evaluated by Mann-Whitney U test for the results of RT-qPCR and with built-in software package limma by moderated t-statistic (http://www.statsci. org/smyth/pubs/limma-biocbook-reprint.pdf) for the results of microarray analysis. The difference was considered statistically significant at $P \leq 0.05$.

\section{Results and Discussion}

Cysteine is undergoing a number of changes in the reactions shown in Fig. 1 and briefly described in the introduction. The level of mRNAs involved in cysteine metabolism reveals the difference between the first and the third trimesters (Table 2). The mRNAs in order of increasing concentrations form the row CSAD, GCLM, CDO, GCLC, SUOX and $A D O$ in the first trimester and the row CSAD, GCLM, GCLC, SUOX, ADO and CDO mRNAs in the third trimester. In the third trimester we observe an increase in the concentration of CDO mRNA against a background of decreasing concentrations of other mRNAs except GCLM mRNA level, which remained almost unchanged. Comparing with the results of the microarray experiments, qPCR showed the same trend in changes in mRNA in the third trimester as in the first, excluding ADO mRNA which, according to data of microarray-experiments, increased slightly, but not significantly (Table 2). The statistical significance of the changes according to microarray-experiments is much lower than with RTqPCR analysis, which is quite expected, because the detection of mRNA on the Affymetrix platforms is based on hybridization of nucleic acids, whereas the method of RT-qPCR is based on multiple amplification of cDNA fragments. Nonsynchronous changes in abundance of all mRNAs indicate differential regulation of gene expression in the first and third trimesters of pregnancy.

The abundance of CDO mRNA and corresponding protein in the third trimester increases more than 10 times first trimester levels (Fig. 2) and raises questions about the mechanism and the role of this event. It is known that CDO is highly expressed in the liver, adipocytes and term placenta [http://www.genecards.org/cgi-bin/
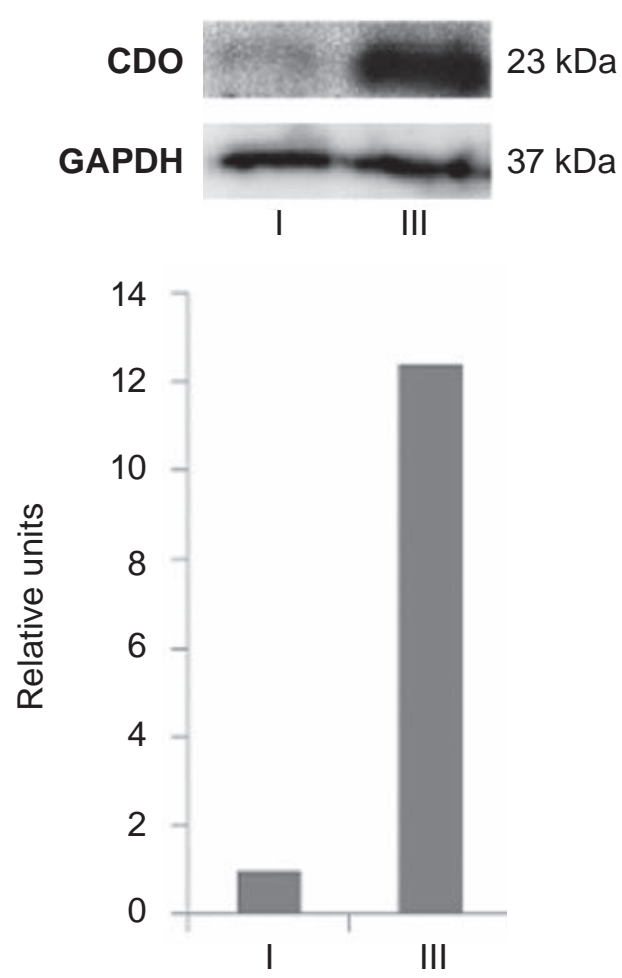

Fig. 2. Electrophoresis and densitometry results of Western Blot Analysis of CDO protein content in placentas from first (I) and third (III) trimesters of pregnancy. Western Blotting was performed using standard technique with anti-cysteine dioxygenase type I antibodies (ab150705; Abcam, Cambridge, UK) and anti-Glyceraldehyde 3-phosphate dehydrogenase antibodies

carddisp.pl?gene $=\mathrm{CDO} 1 \&$ keywords $=$ cysteine, dioxygenase\#expression]. CDO is the most intensively regulated metabolic enzyme [28, 29]. In response to the increased consumption of protein and sulfur-containing amino acids its concentration increases for several hours about 30 to 45 times [28] and its catalytic activity nearly 10 times [29]. Thus, altogether CDO activity increases 300 to 450 times. When someone is on low-protein diet and cysteine level is low, CDO is ubiquitinated and subjected to proteasome degradation and, conversely, its degradation is blocked at high level of cysteine and sulfur-containing amino acids and therefore, CDO concentration increases [30]. Furthemore, the cofactor protein interacts with CDO, stabilizes it and increases its activity [30]. This type of regulation of enzyme activity is observed in the liver, adipose tissue and differentiated adipocytes [7, 30]. How CDO is regulated in human placenta is unknown, although its activity might be essential for the fetus develop- 


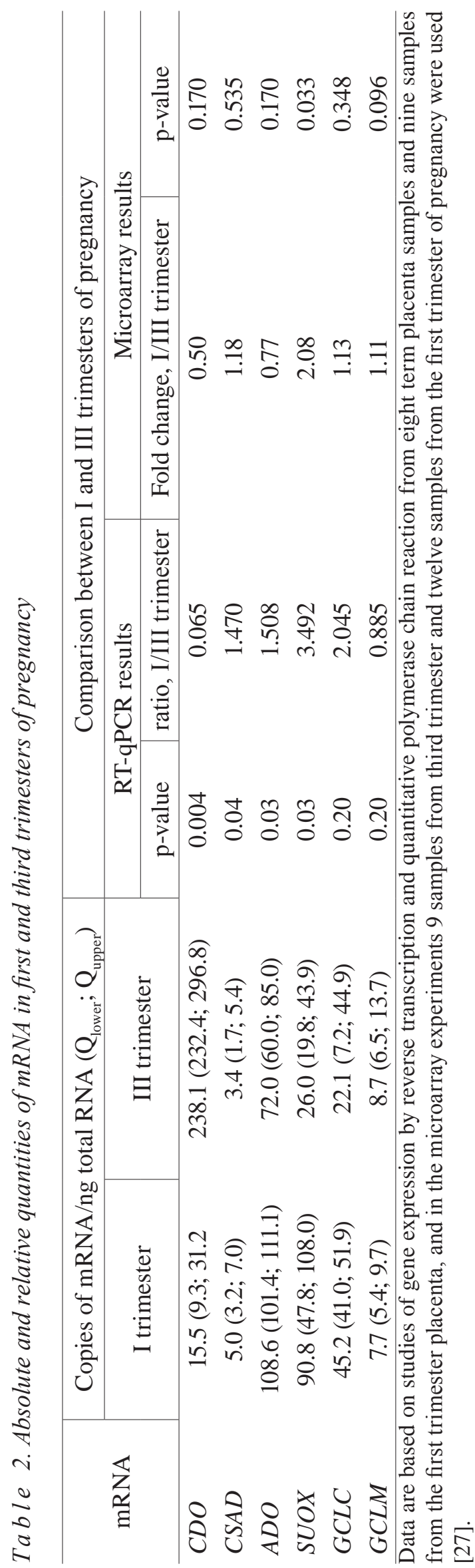

ment as enzyme insufficiency leads to accumulation of cysteine that is cyto- and neurotoxic.

Elevated $C D O$ mRNA abundance in the third trimester indicates an increase in gene expression. Currently, there are very little data on the mechanisms of regulation of $C D O$ gene expression at transcriptional level. It is only known that the low level of $C D O$ transcription is accompanied by high level of methylation of its promoter in cancer cells [31].

Human placentas in the first and third trimesters significantly differ in their structure and weight; in anaerobic and aerobic metabolism; histiotrophic and hemotrophic nutrition; invasive and syncytial phenotype, as well as in alterations of gene expression profiles $[11,27,32,33]$. We suggested that the transition from histiotrophic nutrition in the first trimester to hemotrophic nutrition in the second and third trimesters is accompanied by a greater cysteine supply to placenta and activation of $C D O$ expression via yet unknown mechanism. Under such circumstances the product of CDO enzymatic activity, cysteine sulfinate, might be accumulated followed by activation of transamination, since $K_{\mathrm{m}}$ value of aspartate aminotransferase for cysteine sulfinate $(\sim 3-25 \mathrm{mM})$ is much higher than the $K_{\mathrm{m}}$ of CSAD $[34,35]$.

In turn, the transition from anaerobic metabolism in the first trimester to aerobic in second and third trimesters puts certain requirements to placenta antioxidant system, since the transition would cause oxidative stress. Statistically insignificant reduction of copy number of mRNA encoding the limiting enzyme of glutathione synthesis, GCLC, and unchanged GCLM mRNA abundance should not affect a fairly high level of glutathione synthesis. Glutathione, besides functioning as a main antioxidant, can also act as a repository for cysteine in nontoxic form which can be released on demand through successive reactions glutathione $\rightarrow$ cysteinylglycine $\rightarrow$ cysteine[36].

$A D O, S U O X$ and CSAD mRNA levels are more vulnerable than GCLC and GCLM mRNA levels and their abundance decrease was statistically significant. How it affects the functioning of the placenta is not yet known. But it must be taken into account that even reduced concentration of both individual mRNAs in the total RNA and individual proteins in the total protein offset to a considerable extent by increased organ weight.

The study represents the absolute number of mRNA copies in the total RNA, not just relative changes in mRNA abundance in the first and third 
trimesters of pregnancy, which are often determined in the selective gene expression studies and in microarray-experiments. The method of research enables to compare the abundance of different mRNAs in total tissue RNA. It should be noted that $A D O$ mRNA concentration substantially exceeds the concentration of CSAD mRNA $(\sim 12: 1)$ and all other mRNAs in the study from both pregnancy periods, except $C D O$ mRNA in the third trimester. ADO and CSAD enzymes catalyze the synthesis of hypotaurine/taurine. Taurine is a multifunctional "amino acid" that affects the processes of anti-oxidation, detoxification, osmoregulation. It stabilizes cell membranes, modulates intracellular calcium and exhibits antiinflammatory effect [37]. Taurine is the most represented $(\sim 10 \mathrm{mM})$ "amino acid" in human placenta [38]. It is required for metabolic processes in the trophoblast and for cytoprotection during fetal development, especially for the formation of the central nervous system [39]. At present it is unknown whether placenta is involved in the synthesis of taurine or just in its transport. Taking into account that $A D O$ mRNA concentration in both periods of pregnancy was much higher than CSAD concentration (Table 2) we have suggested that the synthesis of hypotaurine/taurine in placenta occur due to cysteamine oxidation. At the same time we cannot exclude the involvement of mediated by $C D O / C S A D$ metabolic pathway since both mRNAs were at the low level (Table 2) and $K_{\mathrm{m}} C S A D$ value for cysteine sulfinate was low $(\sim 0.04-0.17 \mathrm{Mm})[40,41]$. It is very likely that both processes, the synthesis and transport of taurine can meet the needs of the fetus in taurine, since recent research has shown taurine transporter expression and enzymes of coenzyme A metabolism - a potential precursor of hypotaurine in the human placenta [27, 30, 42].

Thus it has been first provided the data on the level of mRNAs involved in the cysteine metabolism in human placenta in the first and third trimesters of gestation. It has been found that in the third trimester compared to the first the CDO mRNA level is significantly higher, the level of mRNAs responsible for the synthesis of both hypotaurine and sulfate is lower, and the abundance of mRNAs encoding proteins of glutathione synthesis limiting reactions remains almost unchanged. These findings raise the question concerning the regulation of these genes expression and how changes in mRNA concentrations affect the levels of the corresponding proteins and their catalytic activity. This study could contrib- ute to the research of phenotype of human placenta during organ development.

Acknowledgments. This work was supported by the National Academy of Sciences of Ukraine (Project no. 2.2.4.18, 2011-2014).

\section{ЕКСПРЕСІЯ ГЕНІВ, ЩО КОДУЮТЬ ЕНЗИМИ МЕТАБОЛІЗМУ ЦИСТЕЇНУ В ПЛАЦЕНТІ ЛЮДИНИ В ПЕРШОМУ I ТРЕТЬОМУ ТРИМЕСТРАХ НЕУСКЛАДНЕНОЇ ВАГІТНОСТІ}

\author{
К. Л. Корнєєва 1 , Р. Р. Родрігес ${ }^{1}$, \\ С. В. Ральченко ${ }^{2}$, О. В. Мартиновська ${ }^{2}$, \\ А. О. Фролова ${ }^{1}$, О. П. Мариенюк ${ }^{1}$, \\ Л. В. Манжула , В. Т. Мельник', \\ О. Ю. Шкоропад ${ }^{4}$, М. Ю. Оболенська
}

\author{
${ }^{1}$ Інститут молекулярної біології і \\ генетики НАН України, Київ; \\ ${ }^{2}$ Київський національний університет \\ імені Тараса Шевченка, Україна; \\ ${ }^{3}$ Київський міський пологовий \\ будинок № 3, Україна; \\ ${ }^{4}$ Ірпінський пологовий будинок, Україна; \\ e-mail: m.obolenska@gmail.com
}

Вміст цистеїну в клітині регулюється в обмеженому інтервалі концентрацій через його цито- і нейротоксичність у разі перевищення критичного рівня i його брак для синтезу протеїнів й інших життєво важливих метаболітів у разі зниженої концентрації. Механізми регуляції концентрації цистеїну i продуктів його метаболізму, глутатіону, таурину i неорганічних сірковмісних сполук, в плаценті людини практично не досліджені, хоча метаболізм цистеїну тісно пов'язаний 3 підтриманням окисно-відновного статусу і захистом від вільнорадикального окислення, утилізацією гомоцистеїну i детоксикаційною функцією. Ці процеси набувають особливого значення в плаценті, яка зазнає різких змін в концентрації кисню, що надходить на різних етапах її розвитку, і яка є останнім метаболічно активним бар'єром між організмом матері і плода. У зразках плаценти людини 3 першого і третього триместрів неускладненої вагітності ми дослідили експресію генів, що кодують ензими метаболізму цистеїну. Рівень індивідуальних мРHK CDO, CSAD, ADO, SUOX, GCLC і GCLM у складі тотальної РНК оцінювали за реакціями зворотної транскрипції і кількісної ланцюгової 
полімеризації і порівнювали 3 відповідними даними мікромасив-експериментів із бази даних GEO після проведення повторного біоінформативного аналізу. Вміст протеїну визначали вестерн-блот аналізом. У третьому триместрі в порівнянні з першим значно підвищується рівень $C D O$ мРНК, залишається майже незмінним рівень GCLM і GCLC мРНК і різною мірою знижується рівень інших мРНК. У цілому, загальний характер змін збігається 3 результатами мікромасив-експериментів, але на відміну від них $є$ інформативнішим для обмеженої групи генів. Визначені в роботі різні за спрямованістю і величиною істотні відмінності в експресії досліджених генів між першим і третім триместрами вагітності є базовими для подальших досліджень експресії цих ензимів і фенотипу плаценти загалом у нормі і за патології.

К л ю ч о в і с л о в а: плацента людини, ензими метаболізму цистеїну, експресія генів.

\section{ЭКСПРЕССИЯ ГЕНОВ, КОДИРУЮЩИХ ЭНЗИМЫ МЕТАБОЛИЗМА ЦИСТЕИНА \\ В ПЛАЦЕНТЕ ЧЕЛОВЕКА \\ В ПЕРВОМ И ТРЕТЬЕМ ТРИМЕСТРАХ НЕОСЛОЖНЕННОЙ БЕРЕМЕННОСТИ}
Е. Л. Корнеева ${ }^{1}$, Р. Р. Родригес ${ }^{1}$,
С. В. Ральченко ${ }^{2}$, А. В. Мартыновская ${ }^{2}$,
А. А. Фролова 1 , О. П. Мариенюк ${ }^{1}$
Л. В. Манжула, В. Т. Мельник
О. Ю. Шкоропад ${ }^{4}$, М. Ю. Оболенская ${ }^{1}$

${ }^{1}$ Институт молекулярной биологии и генетики НАН Украины, Киев;

${ }^{2}$ Киевский национальный университет имени Тараса Шевченко, Украина;

${ }^{3}$ Киевский городской родильный дом № 3 , Украина;

${ }^{4}$ Ирпенский родильный дом, Украина; e-mail: m.obolenska@gmail.com

Содержание цистеина в клетке регулируется в ограниченном интервале концентраций из-за его цито- и нейротоксичности при превышении критического уровня и недостатка для синтеза протеина и других жизненно важных метаболитов при сниженной концентрации. Механизмы регуляции концентрации цистеина и продуктов его метаболизма, глутатиона, таурина и неорганических серосодержащих соединений в плаценте человека практически не исследованы, хотя метаболизм цистеина тесно связан с поддержанием окислительно-восстановительного потенциала, защитой от свободнорадикального окисления, утилизацией гомоцистеина и способностью к детоксикации. Эти процессы особенно значимы для плаценты, при функционировании которой происходят резкие изменения в концентрации поступающего кислорода, и которая является последним метаболически активным барьером между организмом матери и плода. В образцах плаценты человека первого и третьего триместров неосложненной беременности мы исследовали экспрессию генов, которые кодируют энзимы метаболизма цистеина. Уровень индивидуальных мРНК CDO, CSAD, ADO, SUOX, $G C L C$ и GCLM в составе тотальной РНК оценивали с помощью реакций обратной транскрипции и количественной цепной полимеризации, и результаты сравнивали с соответствующими данными микромассив-экспериментов из базы данных GEO после проведения повторного биоинформатического анализа. Уровень протеина определяли вестерн-блот анализом. В третьем триместре по сравнению с первым существенно повышается уровень $C D O$ мРНК, сохраняется почти неизменным уровень GCLM и GCLC мРНК и в разной степени снижается уровень других мРНК. В целом, общий характер изменений совпадает с результатами микромассив-экспериментов, но в отличие от них является более информативным для ограниченной группы генов. Определенные в работе разные по направленности и величине существенные различия в экспрессии исследованных генов между первым и третьим триместрами беременности являются базовыми для дальнейших исследований экспрессии этих генов в норме и при патологии и для фенотипа плаценты в целом.

К л ю че в ы е с л о в а: плацента человека, энзимы метаболизма цистеина, експрессия генов.

\section{References}

1. Patel J., Landers K., Mortimer R. H., Richard K. Regulation of hypoxia inducible factors (HIF) in hypoxia and normoxia during placental development. Placenta. 2010; 31(11): 951-957.

2. Esterman A., Greco M. A., Mitani Y., Finlay T. H., Ismail-Beigi F., Dancis J. The effect of hypoxia on human trophoblast in culture: 
morphology, glucose transport and metabolism. Placenta. 1997; 18(2-3): 129-136.

3. Adams T., Yeh C., Bennett-Kunzier N., Kinzler W. L. Long-term maternal morbidity and mortality associated with ischemic placental disease. Semin. Perinatol. 2014; 38(3): 146-150.

4. Finkelstein J. D. Methionine metabolism in mammals. J. Nutr. Biochem. 1990; 1(5): 228-237.

5. Finkelstein J. D. Pathways and regulation of homocysteine metabolism in mammals. Semin. Thromb. Hemost. 2000; 26(3): 219-225.

6. Stipanuk M. H., Ueki I. Dealing with methionine/ homocysteine sulfur: cysteine metabolism to taurine and inorganic sulfur. J. Inherit. Metab. Dis. 2011; 34(1): 17-32.

7. Ueki I., Roman H. B., Hirschberger L. L., Junior C., Stipanuk M. H. Extrahepatic tissues compensate for loss of hepatic taurine synthesis in mice with liver-specific knockout of cysteine dioxygenase. Am. J. Physiol. Endocrinol. Metab. 2012; 302(10): E1292-E1299.

8. Gabaldon M. Oxidation of cysteine and homocysteine by bovine albumin. Arch. Biochem. Biophys. 2004; 431(2):178-188.

9. El-Khairy L., Vollset S. E., Refsum H., Ueland P. M. Plasma total cysteine, pregnancy complications, and adverse pregnancy outcomes: the Hordaland Homocysteine Study. Am. J. Clin. Nutr. 2003; 77(2): 467-472.

10. Ottosen L. D., Hindkaer J., Husth M., Petersen D. E., Kirk J., Ingerslev H. J. Observations on intrauterine oxygen tension measured by fibre-optic microsensors. Reprod. Biomed. Online. 2006; 13(3): 380-385.

11. Burton G. J., Watson A. L., Hempstock J., Skepper J. N. and Jauniaux E. Uterine glands provide histiotrophic nutrition for the human fetus during the first trimester of pregnancy. J. Clin. Endocrinol. Metab. 2002; 87(6): 29542959.

12. Stipanuk M. H., Dominy J. E. Jr., Lee J. I., Coloso R. M. Mammalian cysteine metabolism: new insights into regulation of cysteine metabolism. J. Nutr. 2006; 136(6 Suppl): 1652S-1659S.

13. Driggers C. M., Cooley R. B., Sankaran B., Hirschberger L. L., Stipanuk M. H., Karplus P. A. Cysteine dioxygenase structures from $\mathrm{pH} 4$ to 9: consistent cys-persulfenate formation at intermediate $\mathrm{pH}$ and a Cys-bound enzyme at higher pH. J. Mol. Biol. 2013; 425(17): 3121-3136.
14. Rajapakshe A., Tollin G., Enemark J. H. Kinetic and thermodynamic effects of mutations of human sulfite oxidase. Chem. Biodivers. 2012; 9(9): 1621-1634.

15. Dominy J. E. Jr., Simmons C. R., Hirschberger L. L., Hwang J., Coloso R. M., Stipanuk M. H. Discovery and characterization of a second mammalian thiol dioxygenase, cysteaminedioxygenase. J. Biol. Chem. 2007; 282(35): 25189-25198.

16. Stipanuk M. H., Simmons C. R., Karplus P. A., Dominy J. E. Jr. Thiol dioxygenases: unique families of cupin proteins. Amino Acids. 2011; 41(1): 91-102.

17. Sikalidis A. K., Mazor K. M., Lee J. I., Roman H. B., Hirschberger L. L., Stipanuk M. H. Upregulation of capacity for glutathione synthesis in response to amino acid deprivation: regulation of glutamate-cysteine ligase subunits. Amino Acids. 2014; 46(5): 1285-1296.

18. Solanky N., Requena Jimenez A., D’Souza S. W., Sibley C. P., Glazier J. D. Expression of folate transporters in human placenta and implications for homocysteine metabolism. Placenta. 2010; 31(2): 134-143.

19. Mislanova C., Martsenyuk O., Huppertz B., Obolenskaya M. Placental markers of folate-related metabolism in preeclampsia. Reproduction. 2011; 142(3): 467-476.

20. Obolenskaya M. Yu., Rodriguez R. R., Martsenyuk O. P. Folate related processes in human placenta: gene expression, aminothiols, proliferation and apoptosis. Ukr. Biokhim. Zhurn. 2011; 83(1): 5-17.

21. Redman C.W ., Sargent I. L. Placental stress and pre-eclampsia: a revised view. Placenta. 2009; 30(Suppl A): S38-S42.

22. Ditchfield A. M., Desforges M., Mills T. A., Glazier J. D., Wareing M, Mynett K, Sibley C. P., Greenwood S. L. Maternal obesity isassociatedwith a reduction in placental taurinetransporter activity. Int. J. Obes. (Lond). 2015; 39(4): 557-564.

23. Desforges M., Parsons L., Westwood M., Sibley C. P., Greenwood S. L.Taurine transport in human placental trophoblast is important for regulation ofcell differentiation and survival. Cell Death Dis. 2013; 4: e559.

24. Korneyeva K. L, Rodriges R. R., Ralchenko S. V., Vakulenko A. V. , Manzhula L. V., Melnik V. T., Vereshchak O. Yu., Obolenskaya M. Yu. The 
expression of genes encoding key enzyme of folate; dependent metabolism in human placenta in the first and third trimesters of uncomplicated pregnancy. Perinatologiya i Pediatriya. 2014; 4(60): 24-30.

25. Obolenskaya M. Y., Teplyuk N. M., Divi R. L., Poirier M. C., Filimonova N. B., Zadrozna M., Pasanen M. J. Human placental glutathione S-transferase activity and polycyclic aromatic hydrocarbon DNA adducts as biomarkers for environmental oxidative stress in placentas from pregnant women living in radioactivity- and chemically-polluted regions. Toxicol. Lett. 2010; 196(2): 80-86.

26. Guttmacher A. E., Maddox Y. T., Spong C. Y. The Human Placenta Project: placental structure, development, and functioninrealtime. Placenta. 2014; 35(5): 303-304.

27. Mikheev A. M., Nabekura T., Kaddoumi A., Bammler T. K., Govindarajan R., Hebert M. F., Unadkat J. D. Profiling gene expression in human placentae of different gestational ages: an OPRU Network and UW SCOR Study. Reprod. Sci. 2008; 15(9): 866-877.

28. Lee J. I., Londono M., Hirschberger L. L., Stipanuk M. H. Regulation of cysteine dioxygenase and gamma-glutamylcysteine synthetase is associated with hepatic cysteine level. J. Nutr. Biochem. 2004; 15(2): 112-122.

29. Dominy J. E. Jr, Hwang J., Guo S., Hirschberger L. L., Zhang S., Stipanuk M.H. Synthesis of amino acid cofactor in cysteine dioxygenase is regulated by substrate and represents a novel post-translational regulation of activity. J. Biol. Chem. 2008; 283(18): 12188-12201.

30. Stipanuk M. H., Ueki I., Dominy J. E., Jr., Simmons C. R., Hirschberger L. L., Cysteine dioxygenase: a robust system for regulation of cellular cysteine levels. Amino Acids. 2009; 37(1): 55-63.

31. Brait M., Ling S., Nagpal J. K., Chang X., Park H. L., Lee J., Okamura J., Yamashita K., Sidransky D., Kim M. S. Cysteine dioxygenase 1 is a tumor suppressor gene silenced by promoter methylation in multiple human cancers. PLoS One. 2012; 7(9): e44951.

32. Huppertz B. Maternal-fetal interactions, predictive markers for preeclampsia, and programming. J. Reprod. Immunol. 2015; 108: 26-32.

33. Morrish D. W., Dakour J., Li H. Functional regulation of human trophoblast differentiation. J. Reprod. Immunol. 1998; 39(1-2): 179-195.

34. Recasens M., Benezra R., Basset P., Mandel P. Cysteine sulfinate aminotransferase and aspartate aminotransferase isoenzymes of rat brain. Purification, characterization and further evidence for identity. Biochemistry. 1980; 19(20): 4583-4589.

35. Yagi T., Kagamiyama H., Nozaki M. Cysteine sulfinate transamination activity of aspartate aminotransferase. Biochem. Biophys. Res. Commun. 1979; 90(2): 447-452.

36. Meister A. Glutathione metabolism and its selective modification. J. Biol. Chem. 1988; 263(33): 17205-17208.

37. Tappaz M. L. Taurine biosynthetic enzymes and taurine transporter: molecular identification and regulations. Neurochem. Res. 2004; 29(1): 8396.

38. Philipps A. F., Holzman I. R., Teng C., Battaglia F. C. Tissue concentrations of free amino acids in term human placentas. Am. J. Obstet. Gynecol. 1978; 131(8): 881-887.

39. Ripps H., Shen W. Review: taurine: a "very essential" amino acid. Mol. Vis. 2012; 18: 26732686.

40. Guion-Rain M. C., PortemerC., Chaatagner F. Rat liver cysteine sulfinate decarboxylase: purification, new appraisal of the molecular weight and determination of catalytic properties. Biochim. Biophys. Acta. 1975; 384(1): 265-276.

41. Oertel W. H., Schmechel D. E., Weise V. K., Ransom D. H., Tappaz M. L., Krutzsch H. C., Kopin I. J. Comparison of cysteine sulphininc acid decarboxylase isoenzymes and glutamic acid decarboxylase in rat liver and brain. Neuroscience. 1981; 6(12): 2701-2714.

42. Desforges M., Parsons L., Westwood M., Sibley C. P., Greenwood S.L. Taurine transport in human placental trophoblast is important for regulation of cell differentiation and survival. Cell Death Dis. 2013; 4: e559.

Received 21.07.2015 